\title{
Isolation and biochemical characterization of phytase from different sources
}

\begin{abstract}
Phytase (myo-inositolhexakisphosphate phosphohydrolase) catalyzes the hydrolysis of myo-inositol hexakisphosphate (phytic acid) to inorganic monophosphate and lower myo-inositol phosphates and in some cases to free myo-inositol. Two bacterial strains, one fungal strain and one plant source were screened for phytate degradation viz. Escherichia coli (ATCC 25922), Bacillus subtilis (ATCC 6633), Aspergillus niger (ATCC 16888) and Glycine max (JS-335). Among these, B. subtilis (ATCC 6633) strain was found to produce maximum clearance zone of $2.7 \mathrm{~cm}$ on phytase screening medium containing sodium phytate as substrate, incubated at $37^{\circ} \mathrm{C}$ for 48 hours. Phytase was isolated from $B$. subtilis (ATCC 6633), which was able to withstand temperature ranging from $40^{\circ} \mathrm{C}$ to $50^{\circ} \mathrm{C}, \mathrm{pH} 4.0-6.0$ and showed maximum activity at $50^{\circ} \mathrm{C}$ and $6.0 \mathrm{pH}$. However, phytase isolated from E.coli (ATCC 25922), A.niger (ATCC 16888) and Glycine max (JS-335) were able to withstand temperature ranging from $37.5^{\circ} \mathrm{C}$ to $45^{\circ} \mathrm{C}$ only and at $\mathrm{pH} 3.5-5.0$.
\end{abstract}

Keywords: phytase, B. subtilis, pH; temperature, escherichia coli, inositol, a.niger, dephosphorylation
Volume 2 Issue 4 - 2017

Chaitanya Mogal, Diwakar Singh, Amit Mehta, Taslim Ahmad, Kiran Suthar

Department of Plant Molecular Biology and Biotechnology, Navsari Agriculture University, India

Correspondence: Chaitanya Mogal, Department of Plant Molecular Biology and Biotechnology, Navsari Agriculture University, Navsari- 396450, Gujarat, India, Email chaitanya.mogal29@gmail.com

Received: February 15, 2017| Published: March 14, 2017
Abbreviations: NA, nutrient agar; LB, luria-bertani; PDA, potato dextrose agar

\section{Introduction}

Phytase, or myo-inositol hexakisphosphate phosphohydrolase (EC 3.1.3.8), was first discovered by. ${ }^{1,2}$ The principal end products of phytase action are phosphoric acid and myo-inositol, but the phosphatidylinositols representing various degrees of dephosphorylation from inositol hexakisphosphate to inositol are generated as intermediates. Phytate, an inhibitor of iron absorption, can be degraded by phytase. Phytase is an ester hydrolyzing enzyme with an estimated molecular mass of $35-700 \mathrm{kDa}$ depending upon the sources of origin. Phytase genes have been isolated from plants, ${ }^{3}$ bacteria $^{4}$ and fungi ${ }^{5,6}$ (Figure 1). Although phytase shows a potential to be utilized for phytate bioconversion, the enzyme activities and yields need to be increased to make them possible for industrial application. Therefore, it is important to isolate a variety of different microorganisms and their enzymes for phytate degradation. ${ }^{7}$ The $\mathrm{pH}$ optimum of phytases varies from 2.2 to 8 . Most microbial phytases, especially those of fungal origin, have a $\mathrm{pH}$ optimum between 4.5 and 5.6. In contrast to most fungal phytases, A. fumigatus phytase has a broad pH optimum; at least $80 \%$ of the maximal activity is observed at $\mathrm{pH}$ values between 4.0 and 7.3. Some bacterial phytases, especially those from Bacillus, have a $\mathrm{pH}$ optimum at 6.5-7.5. The $\mathrm{pH}$ optima of plant seed phytases range from 4.0 to 7.5 , most having an optimum between 4.0 and 5.6. The temperature optima of phytases vary from 45 to $77^{\circ} \mathrm{C}$. This paper describes a phytase isolated from different sources and their study of enzyme activity at different $\mathrm{pH}$ and temperatures.

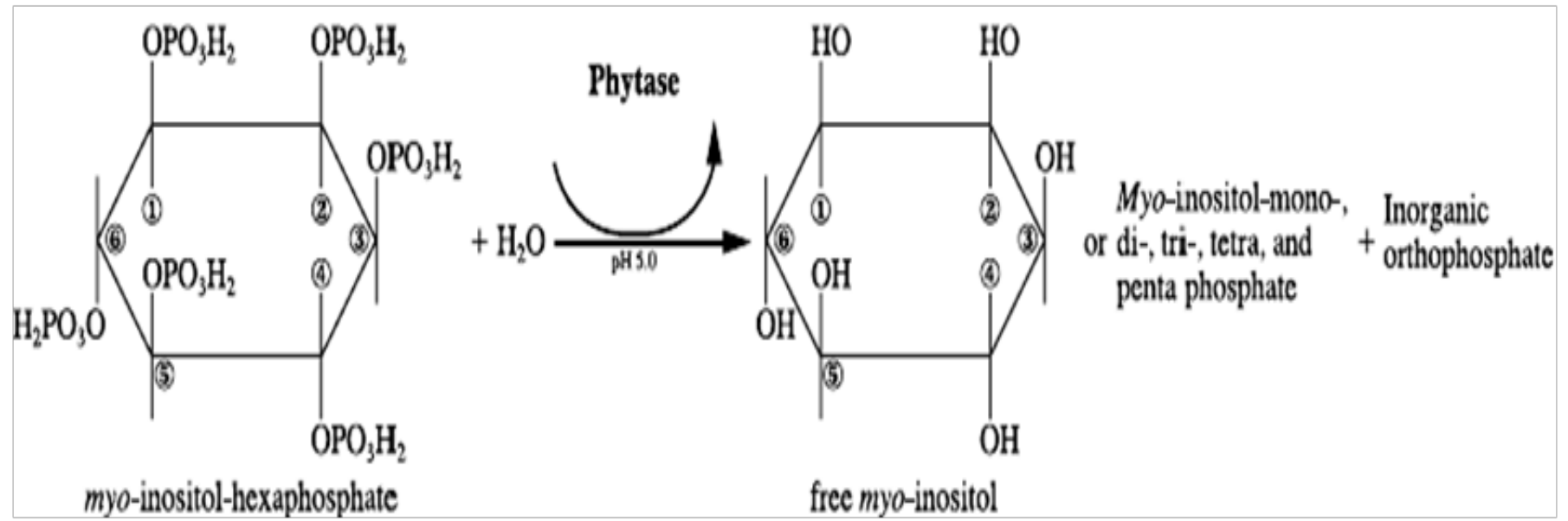

Figure I Hydrolysis of phytic acid by phytase enzyme. 


\section{Materials and methods}

The investigation was carried out using four organisms viz., Escherichia coli (ATCC 25922), Bacillus subtilis (ATCC 6633), Aspergillus niger (ATCC 16888) and Glycine max (JS-335). Escherichia coli (ATCC 25922), Bacillus subtilis (ATCC 6633) were grown at $37^{\circ} \mathrm{C}$ on Nutrient Agar (NA) and Luria-Bertani (LB) agar medium respectively. Aspergillus niger (ATCC 16888) was grown at $37^{\circ} \mathrm{C}$ on Potato Dextrose Agar (PDA) medium. The seeds of soybean variety (JS-335) were procured from Pulse Research Station, Navsari Agricultural University, Navsari and 9 days old seedlings were used for enzyme assay.

\section{Biochemical characterization}

Growth studies at different temperature and $\mathrm{pH}$ concentrations: To study the definite growth pattern of the isolates, first temperature and $\mathrm{pH}$ requirements were optimized for each strain.

Temperature optimization: Tubes of media were equally inoculated with fresh culture in duplicates and incubated in the range of $35-55^{\circ} \mathrm{C}$ (with an interval of $2.5^{\circ} \mathrm{C}$ ). After $72 \mathrm{hrs}$, growth on particular media was measured by spectrophotometer at $820 \mathrm{~nm}$.

pH optimization: Tubes of media at different $\mathrm{pH}$ range 3.0 to 7.0 (with an interval of $0.5 \mathrm{pH}$ ) were prepared in duplicates and after inoculation incubated at respective optimum temperature for each strain. After $72 \mathrm{~h}$, growth on particular media was measured by spectrophotometer at $820 \mathrm{~nm}$.

Screening for the efficient phytate degrading bacteria: Isolates that produced clearance zone were then plated on phytase screening medium containing calcium phytate as substrate. The clearance zone and colony diameter were measured after $2-5$ days of incubation at $37^{\circ} \mathrm{C}$.

Phytase enzyme assay: Bacterial and fungal strains were grown in 50 $\mathrm{ml}$ of liquid medium containing $0.1 \%$ sodium phytate, $1 \%$ peptone, $0.2 \%\left(\mathrm{NH}_{4}\right)_{2} \mathrm{SO}_{4}, 0.05 \% \mathrm{KCl}, 0.05 \% \mathrm{MgSO}_{4} .7 \mathrm{H}_{2} \mathrm{O}, 0.03 \% \mathrm{MnSO}_{4}$, $0.03 \% \mathrm{FeSO}_{4} .7 \mathrm{H}_{2} \mathrm{O}, \mathrm{pH} 7.5 \mathrm{in}$ a $250 \mathrm{ml}$ flask and incubated at $50^{\circ} \mathrm{C}$ for three days on a rotary shaker at 200rpm. Crude enzyme was harvested by centrifugation at $10,000 \mathrm{~g}$ for $10 \mathrm{mins}$ at $4^{\circ} \mathrm{C}$ and the clear supernatant was used as the source of extracellular phytases. For extraction of phytase from soybean, $1 \mathrm{~g}$ of seeds was ground to a fine powder in a prechilled mortar and pestle. To this powder, $100 \mathrm{ml}$ of chilled extraction buffer [0.02M Tris- $\mathrm{HCl}(\mathrm{pH} 7.6)$ containing $0.1 \%$ Triton $\mathrm{X}-100]$. The mixture was homogenized until a uniform slurry was obtained and then centrifuged at $12,000 \mathrm{~g}$ for $30 \mathrm{~min}$ at $4^{\circ} \mathrm{C}$. The supernatant was used for phytase assays. ${ }^{4}$

Sodium phytate was used as substrate for assaying the activity of phytase. Phytase activity was determined by measuring the amount of liberated inorganic phosphate. The reaction mixture consisted of sodium phytate (Hi media; $0.5 \% \mathrm{w} / \mathrm{v}$ ) prepared in sodium acetate buffer $(0.2 \mathrm{M}, \mathrm{pH} 5.5)$ and $0.2 \mathrm{ml}$ of supernatant. After incubation at $50^{\circ} \mathrm{C}$ for $30 \mathrm{mins}$, the reaction was stopped by adding an equal volume of $15 \%$ trichloroacetic acid. The liberated phosphate ions were quantified by mixing $100 \mu \mathrm{l}$ of assay mixture with $900 \mu \mathrm{l}$ of $1.0 \mathrm{M}$ $\mathrm{H}_{2} \mathrm{SO}_{4}-10 \%$ ascorbic acid- $2.5 \%$ ammonium molybdate (3:1:0.1) $(\mathrm{v} / \mathrm{v})$. After 20 mins of incubation at $50^{\circ} \mathrm{C}$, absorbance was measured at $820 \mathrm{~nm}$.

\section{Results and discussion}

In the present study, two bacterial strains (B. subtilis and E. coli), one fungal strain (A. niger) and one plant source (G.max) were screened for phytate degradation. Among the isolates, B. subtilis (ATCC 6633) strain were found to possess maximum phytate degrading capacity which was identified by the presence of clearance zone in phytase screening medium containing sodium phytate as substrate. The result agreed with ${ }^{1}$ who stated that the growth on plates was suggested to be easier than in a liquid medium for phytate degrading bacteria. The organisms obtained by spread plate method on phytase screening medium containing sodium phytate as substrate are shown in Figure 2. B. subtilis (ATCC 6633) strain was found to produce maximum clearance zone of $2.7 \mathrm{~cm}$ on phytase screening medium containing sodium phytate as substrate, incubated at $37^{\circ} \mathrm{C}$ for 48 hours. E. coli strain (ATCC 25922) and fungal strain i.e. Aspergillus niger (ATCC 16888) also produced clearance zone but the diameter of the clearance zone and growth of the organism was less compared to B. subtilis (Figure 3).

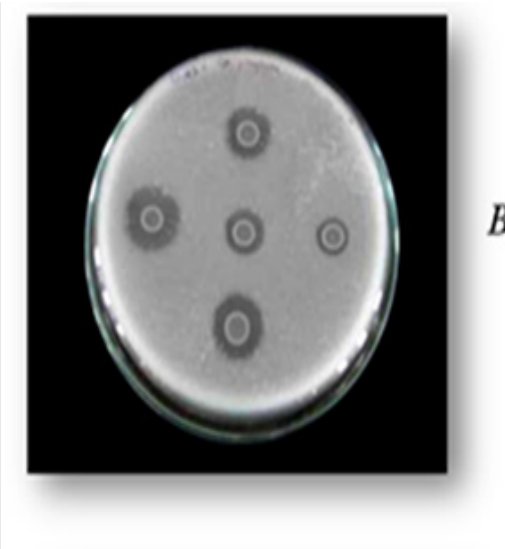

B. subtilis

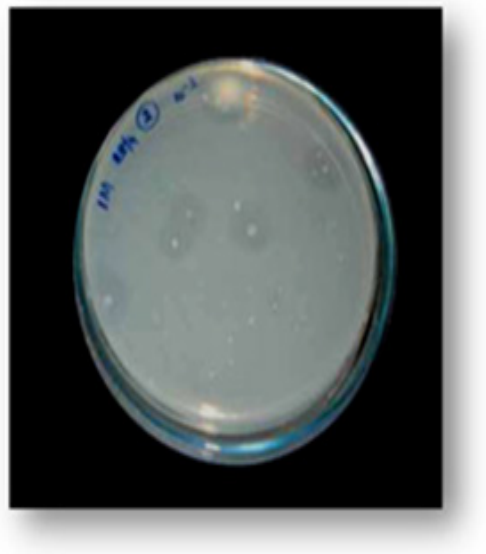

E.coli

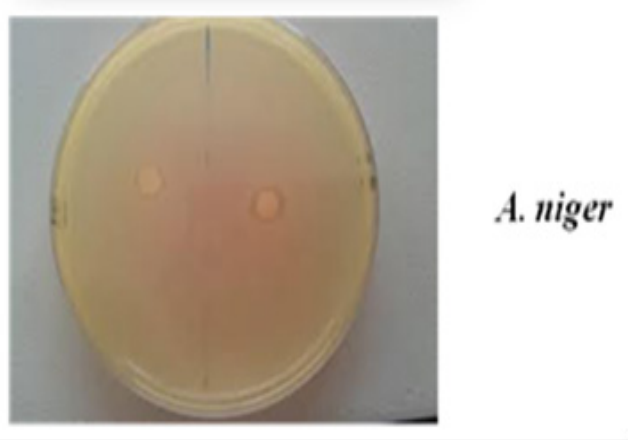

Figure 2 Clearance zone around the organisms when the sample was spread plated on phytase screening medium containing sodium phytate. 


\section{Phytase enzyme activity at different $\mathrm{pH}$ and tempe- rature}

After analysing the results on different $\mathrm{pH}$ it was observed that phytase enzyme isolated from $B$. subtilis posses maximum enzyme activity i.e. $4.20 \pm 0.02 \mathrm{Uml}^{-1}$ at $\mathrm{pH} 6.0$, where as E.coli, Aspergillus niger and Glycine max showed maximum enzyme activity i.e. $2.90 \pm 0.01,2.90 \pm 0.01$ and $2.75 \pm 0.01$ respectively at $\mathrm{pH} 5.0$ (Table 1 and Figure 3). After pH 6.0 there was reduction in enzyme activity of B. subtilis, where as in other organisms E.coli, Aspergillus niger and Glycine max after pH 5.0 the enzyme activity was reduced (Figure 3). Thus, based on maximum enzyme activity it may be said that phytase enzyme of $B$. subtilis may be more useful compared to other sources.
Phytase enzyme of $B$. subtilis may perform better under acidic condition because at pH 5.0 also it showed higher activity i.e. $3.30 \pm 0.01 \mathrm{Uml}^{-1}$ compared to other organisms. After analysing the results on different temperature it was observed that phytase enzyme isolated from $B$. subtilis posses maximum enzyme activity i.e. $4.20 \pm 0.02 \mathrm{Uml}^{-1}$ at temperature $50^{\circ} \mathrm{C}$, where as E.coli, Aspergillus niger and Glycine max showed maximum enzyme activity i.e. $2.67 \pm 0.01,2.85 \pm 0.01$ and $2.90 \pm 0.02$ respectively at temperature $45^{\circ} \mathrm{C}$ (Table $2 \&$ Figure 4). After $50^{\circ} \mathrm{C}$ there was reduction in enzyme activity of $B$. subtilis, where as in other organisms E.coli, Aspergillus niger and Glycine max after $45^{\circ} \mathrm{C}$ the enzyme activity was reduced (Figure 4). Thus, phytase enzyme of $B$. subtilis may be more thermostable compared to other sources.

Table I Phytase enzyme activity at different $\mathrm{pH}$

\begin{tabular}{|c|c|c|c|c|}
\hline $\mathrm{pH}$ & B. subtilis & E. coli & A. niger & G.max \\
\hline 3 & $3.00 \pm 0.02 *$ & $2.75 \pm 0.0 I^{*}$ & $2.45 \pm 0.09 *$ & $1.88 \pm 0.0 I^{*}$ \\
\hline 3.5 & $3.10 \pm 0.01 *$ & $2.78 \pm 0.02^{*}$ & $2.48 \pm 0.02 *$ & $2.00 \pm 0.05^{*}$ \\
\hline 4 & $3.20 \pm 0.04 *$ & $2.80 \pm 0.09 *$ & $2.50 \pm 0.01 *$ & $2.27 \pm 0.02 *$ \\
\hline 4.5 & $3.27 \pm 0.02 *$ & $2.79 \pm 0.02 *$ & $2.70 \pm 0.02 *$ & $2.35 \pm 0.0 I^{*}$ \\
\hline 5 & $3.30 \pm 0.01 *$ & $2.90 \pm 0.01 *$ & $2.90 \pm 0.01 *$ & $2.75 \pm 0.01 *$ \\
\hline 5.5 & $3.50 \pm 0.01 *$ & $2.85 \pm 0.02 *$ & $2.86 \pm 0.01 *$ & $2.60 \pm 0.02 *$ \\
\hline 6 & $4.20 \pm 0.01 *$ & $2.80 \pm 0.0 I^{*}$ & $2.79 \pm 0.01 *$ & $2.56 \pm 0.02 *$ \\
\hline 6.5 & $3.10 \pm 0.01 *$ & $2.78 \pm 0.02 *$ & $2.60 \pm 0.02 *$ & $2.40 \pm 0.0 I^{*}$ \\
\hline 7 & $3.00 \pm 0.01 *$ & $2.50 \pm 0.0 I^{*}$ & $2.50 \pm 0.02 *$ & $2.25 \pm 0.0 \mathrm{I} *$ \\
\hline S.Em. & 0.059 & 0.062 & 0.059 & 0.058 \\
\hline C.D at $5 \%$ & 0.32 & 0.18 & 0.17 & 0.17 \\
\hline C.V.\% & 3.27 & 3.43 & 3.31 & 3.25 \\
\hline
\end{tabular}

*The values are depicted as Mean \pm S.D. of 5 independent observations.

Table 2 Phytase enzyme activity at different temperature $\left({ }^{\circ} \mathrm{C}\right)$

\begin{tabular}{|c|c|c|c|c|}
\hline Temp $\left({ }^{\circ} \mathrm{C}\right)$ & B. subtilis & E. coli & A. niger & G.max \\
\hline 35 & $2.00 \pm 0.01 *$ & $1.99 \pm 0.01 *$ & $1.85 \pm 0.02 *$ & $1.95 \pm 0.01 *$ \\
\hline 37.5 & $2.25 \pm 0.02 *$ & $2.10 \pm 0.02 *$ & $2.22 \pm 0.01 *$ & $2.00 \pm 0.0 I^{*}$ \\
\hline \pm 40.0 & $2.46 \pm 0.01 *$ & $2.35 \pm 0.0 \mathrm{I} *$ & $2.45 \pm 0.02 *$ & $2.50 \pm 0.0 I^{*}$ \\
\hline 42.5 & $2.60 \pm 0.0 I^{*}$ & $2.55 \pm 0.0 \mathrm{I} *$ & $2.65 \pm 0.0 I^{*}$ & $2.67 \pm 0.02^{*}$ \\
\hline 45 & $2.60 \pm 0.01 *$ & $2.67 \pm 0.0 \mathrm{I} *$ & $2.85 \pm 0.01 *$ & $2.90 \pm 0.02 *$ \\
\hline 47.5 & $2.88 \pm 0.01 *$ & $2.50 \pm 0.01 *$ & $2.60 \pm 0.02 *$ & $2.80 \pm 0.01 *$ \\
\hline 50 & $4.20 \pm 0.02 *$ & $2.40 \pm 0.02 *$ & $2.45 \pm 0.01 *$ & $2.67 \pm 0.0 \mathrm{I} *$ \\
\hline 52.5 & $3.50 \pm 0.01 *$ & $2.20 \pm 0.01 *$ & $2.25 \pm 0.02 *$ & $2.45 \pm 0.0 \mathrm{I} *$ \\
\hline 55 & $3.35 \pm 0.01 *$ & $1.98 \pm 0.01 *$ & $1.88 \pm 0.02 *$ & $2.10 \pm 0.01 *$ \\
\hline S.Em. & 0.085 & 0.064 & 0.079 & 0.091 \\
\hline C.D at $5 \%$ & 0.25 & 0.19 & 0.23 & 0.27 \\
\hline C.V.\% & 4.91 & 3.68 & 4.64 & 5.24 \\
\hline
\end{tabular}

*The values are depicted as Mean \pm S.D. of 5 independent observations. 


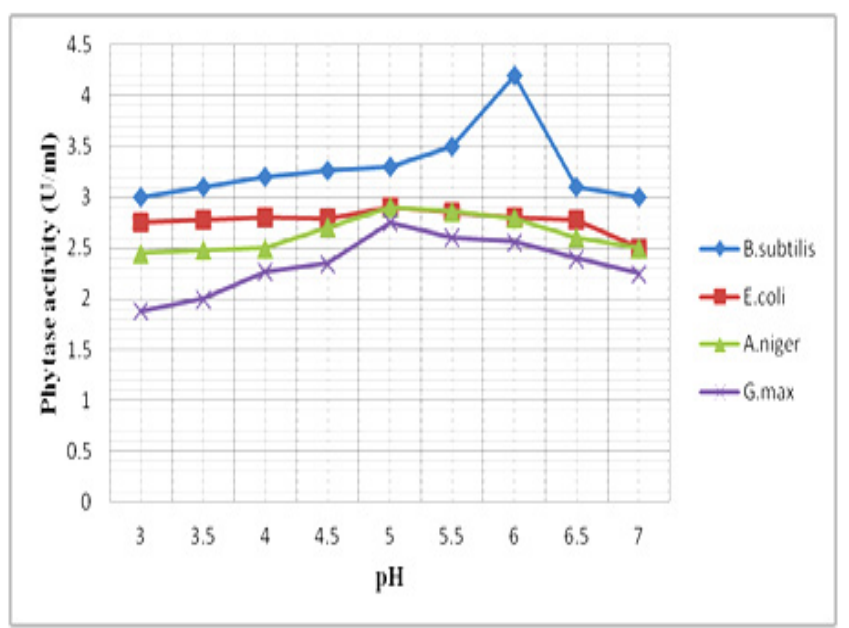

Figure 3 Phytase activity at different $\mathrm{pH}$.

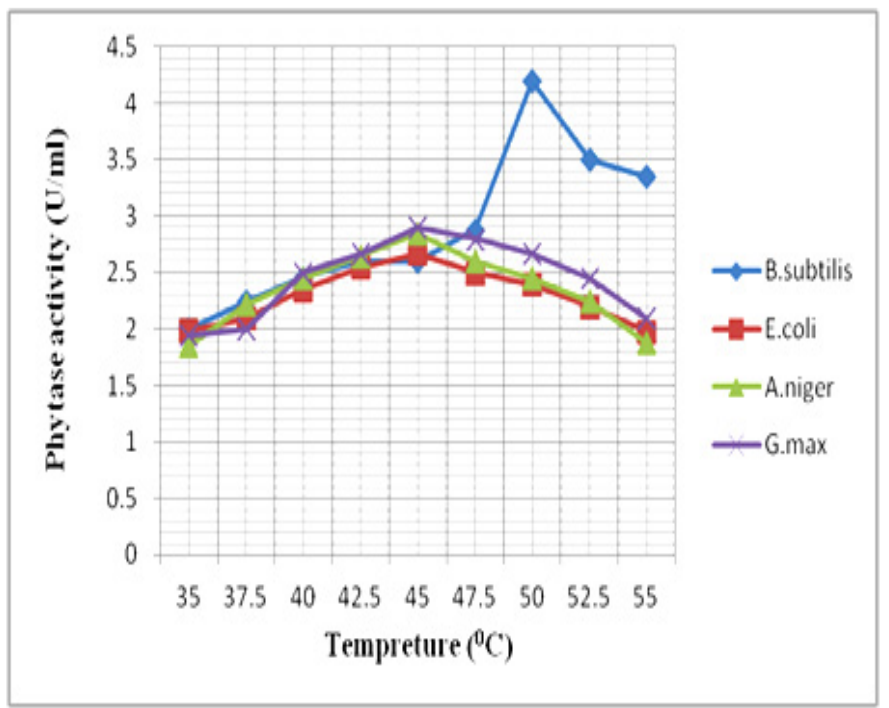

Figure 4 Phytase activity at different temperature.

\section{Conclusion}

Our finding suggests that phytase enzyme isolated from B. subtilis (ATCC 6633) has significant values which can be exploited for industrial production of phytase. Moreover, this enzyme can be used in the animal feed industry for improving the nutritional status of feed and in combating environmental pollution.

\section{Acknowledgements}

None.

\section{Conflict of interest}

The author declares no conflict of interest.

\section{References}

1. Suzuki U, Yoshimura K, Takaishi M. Ueberein enzym phytase das anhydro-oxy-methilen diphos-phorusaure spaltet. Bulletin of the College of Agriculture, Japan. 1907;7:503-512.

2. Wyss M, Pasamontes L, Rémy R, et al. Comparison of the thermostability properties of three acid phosphatases from molds: Aspergillus fumigatus phytase, A. niger phytase, and A. niger $\mathrm{pH} 2.5$ acid phosphatase. Appl Environ Microbiol. 1998;64(11):4446-4451.

3. Rodriguez E, Han Y, Lei XG. Cloning, sequencing and expression of an Escherichia coli acid phosphatase, phytase gene (appA2) isolated from pig colon. Biochem Biophys Res Commun. 1999;257(1):117-123.

4. Scott JJ. Alkaline phytase activity in nonionic detergent extracts of legume seeds. Plant Physiol. 1991;95(4):1298-1301.

5. Pasamontes L, Haiker M, Wyss M, et al. Gene cloning, purification and characterization of a heat-stable phytase from the fungus Aspergillus fumigates. Appl Environ Microbiol. 1997;63(5):1696-1700.

6. Reddy NR, Sathe SK, Salunkhe DK. Phytates in legumes and cereals. Advances in Food Research. 1982;28:1-92 .

7. Choi YM, Suh HJ, Kim JM. Purification and properties of extracellular phytase from Bacillus sp. KHU-10. J Protein Chem. 2001;20(4):287292

8. Mittal A, Singh G, Goyal V, et al. Isolation and biochemical characterization of acido-thermophilic extracellular phytase producing bacterial strain for potential application in poultry feed. Jundishapur J Microbiol. 2011;4(4):273-282. 